\title{
IMPACTOS TERRITORIAIS E AMBIENTAIS NOS CONFLITOS POSSESSÓRIOS COM AS EMPRESAS SUZANO E PAINEIRAS NO BAIXO PARNAÍBA MARANHENSE
}

\author{
Ruan Didier Bruzaca ${ }^{1}$ \\ Universidade Federal do Maranhão (UFMA)
}

Adriana Dias Vieira ${ }^{2}$

Universidade Federal Fluminense (UFF)

\section{RESUMO}

Os conflitos territoriais e ambientais provocados pelo agronegócio na microrregião do Baixo Parnaíba maranhense, como aqueles envolvendo as empresas Suzano e Paineiras, são geridos por diferentes instrumentos administrativos e jurídicos que podem incorrer no risco de agudizá-los, de conformar os sujeitos afetados e de desconsiderar aspectos étnicos e culturais envolvidos. Diante dessa temática, delimita-se a abordagem nas modificações territoriais e ambientais decorrentes de ações possessórias envolvendo os empreendedores do agronegócio em tal microrregião. Com isso, inicialmente, tem-se como objetivo destacar o panorama do uso das ações possessórias no Baixo Parnaíba maranhense, enfatizando os conflitos envolvendo a Suzano e a Paineiras. Em seguida, examinar-se-ão as correlações entre o referido instrumento processual e o agronegócio. Por fim, será abordado o choque cultural mediante os grupos sociais afetados pelos empreendimentos, principalmente camponeses. Metodologicamente, utiliza-se pesquisa bibliográfica e documental, com o levantamento de ações possessórias que envolvem as referidas empresas no Baixo Paranaíba maranhense. Aqui, realiza-se estudo de caso e análise qualitativa de conteúdo, combinado com análise global. Como conclusão, observa-se que a prática jurídica alinhada à manutenção do exercício da posse em favor

1 Doutorando em Ciências Jurídicas pela Universidade Federal da Paraíba (UFPB), com período sanduíche na Universitá degli Studi di Firenze (UNIFI). Mestre em Direito e Instituições do Sistema de Justiça pela Universidade Federal do Maranhão (UFMA). Graduado em Direito pela Unidade de Ensino Superior Dom Bosco (UNDB). Professor da UFMA e da UNDB. E-mail: ruandidier@gmail. com.

2 Doutora em Direito pela Università degli Studi di Firenze (UNIFI). Doutora em Sociologia pela Universidade Federal da Paraíba (UFPB). Mestre em Direito pelo Programa de Pós-Graduação em Ciências Jurídicas da UFPB. Professora adjunta III da Faculdade de Direito da Universidade Federal Fluminense (UFF). Professora permanente do Programa de Pós-Graduação em Ciências Jurídicas (PPGCJ/UFPB). E-mail: a.diasvieira@gmail.com. 
das empresas resulta no aumento de impactos territoriais e ambientais, diferente da atuação voltada para o acesso à terra das comunidades.

Palavras-chave: ações possessórias; agronegócio; Baixo Parnaíba maranhense; camponeses; conflitos territoriais e ambientais.

\author{
TERRITORIAL AND ENVIRONMENTAL IMPACTS IN THE \\ POSSESSIONAL CONFLICTS WITH THE SUZANO AND PAINEIRAS \\ COMPANIES IN THE BAIXO PARNAÍBA MARANHENSE
}

\title{
ABSTRACT
}

The territorial and environmental conflicts caused by agribusiness in the micro-region of Baixo Parnaiba of Maranhão, such as those involving Suzano and Paineiras, are managed by different administrative and legal instruments that may incur the risk of aggravating them, of conforming the affected subjects, and of disregarding ethnic and cultural aspects involved. Facing this theme, the approach is limited in the territorial and environmental modifications resulting from possessory actions involving agribusiness entrepreneurs in such micro-region. With this, the initial aim is to highlight the panorama of the use of possessory actions in Baixo Parnaiba of Maranhão, emphasizing the conflicts involving Suzano and Paineiras. Next, to examine the correlations between those procedural instrument and agribusiness. Finally, to address the cultural shock to the social groups affected by the enterprises, mainly peasants. Methodologically, bibliographical and documentary research is used, with the survey of possessory actions involving the said companies in Baixo Paranaiba, Maranhão. Here, a case study and qualitative content analysis are combined with global analysis. As conclusion, it is observed that the legal practice aligned to the maintenance of the exercise of ownership in favor of the companies results in the increase of territorial and environmental impacts, different from the action focused on the access to the land of the communities.

Keywords: agribusiness; Baixo Parnaiba maranhense; peasants; possessory actions; territorial and environmental conflicts. 


\section{INTRODUÇÃO}

A microrregião do Baixo Parnaíba maranhense ${ }^{3}$ é marcada por diversos conflitos fundiários, como aqueles provocados pelo agronegócio. Nesse cenário, vários são os atores econômicos que intervêm na localidade com atividade de monocultivo, como a soja e o eucalipto. Entre os atores, estão as empresas Suzano Papel e Celulose e a Comercial Agrícola Paineiras, as quais estão envolvidas em conflitos com comunidades e exemplificam o problema ora analisado no presente artigo.

O contex to dos conflitos envolvendo agronegócio e comunidades rurais no Baixo Parnaíba maranhense data de décadas atrás. Resumidamente, Gaspar e Andrade (2014) destacam que desde 1980 a região passou por drásticas mudanças ambientais em razão de atividades agroindustriais, como com os plantios de eucalipto pela Suzano e pela Paineiras. Durante os anos 1990 e 2000, houve crescimento das atividades com a inclusão da produção de soja. A expansão do agronegócio no Maranhão foi ainda possibilitada pela infraestrutura do estado, com o escoamento de grande produção em razão de rodovias, ferrovias e portos, como é o caso do porto do Itaqui. Esse avanço implicou a questionável apropriação de terras pelos empreendedores, ao passo que agudizou a fragilização da posse de comunidades rurais na região.

Assim sendo, o problema sociojurídico apresentado no presente artigo diz respeito às implicações da prática jurídica na manutenção de conflitos territoriais e impactos ambientais entre comunidades locais e as empresas Suzano e Paineiras no Baixo Paraíba maranhense, envolvendo questões possessórias. Quanto ao objetivo geral, busca-se analisar em que medida as ações possessórias repercutem na continuidade com modificações territoriais e ambientais. Especificamente, pretende-se: (i) identificar as ações possessórias no Baixo Parnaíba maranhense envolvendo a Suzano e a Paineiras; (ii) examinar as correlações entre o referido instrumento processual e o agronegócio; e (iii) verificar o embate face aos grupos étnico-culturais afetados pelos empreendimentos.

Para tal, foi realizada pesquisa documental, com o levantamento de ações possessórias no Baixo Paranaíba maranhense que tenham como parte as empresas Suzano e Paineiras; utilizou-se como fonte de dados

3 A microrregião do Baixo Parnaíba maranhense é formada pelos municípios de Água Doce do Maranhão, Anapurus, Araioses, Belágua, Chapadinha, Magalhães de Almeida, Mata Roma, Santa Quitéria, Santana do Maranhão, São Benedito do Rio Preto, São Bernardo, Tutóia e Urbano Santos (BRASIL, 2005, p. 8). 
as informações constantes no Jurisconsult, sítio de pesquisa processual eletrônica do Poder Judiciário do Estado do Maranhão. O levantamento foi realizado selecionando-se as ações que estão inseridas no cenário de conflitos com comunidades tradicionais e, ao constatar a existência de três casos na comarca de Santa Quitéria do Maranhão, realizou-se uma pesquisa de campo na localidade para ter acesso aos autos processuais.

Assim, combinaram-se o estudo de caso e a utilização da análise qualitativa de conteúdo, que consiste, segundo Flack (2009, p. 291), em "um dos procedimentos clássicos para analisar o material textual", por meio da descrição exata ou a reconstrução de um caso. O material textual analisado consistiu em petições iniciais, contestações, recursos, decisões liminares, petições intermediárias, decisões em segunda instância e sentenças referentes aos casos selecionados. Assim, possibilitou-se identificar os sentidos utilizados na prática jurídica que se alinham ou não à continuidade do agronegócio na região.

Utilizou-se também a análise explicativa do conteúdo, visando esclarecer trechos do material selecionado conforme a "síntese de análise de conteúdo", que busca resumir o material coletado e explicá-lo (FLICK, 2009, p. 292). Ademais, suplementa-se essa análise de conteúdo com análise global que, segundo Flack (2009, p. 294) possibilita "uma visão geral do alcance temático do texto a ser analisado".

Quanto ao referencial teórico, na área jurídica, aproxima-se de marcos do pensamento jurídico crítico e da sociologia jurídica, como é o caso de Antônio Carlos Wolkmer (2001) e Michel Miaille (2005). Por tratar do agronegócio, dialoga com autores que estudam as relações coloniais entre saber e poder e o discurso do desenvolvimento, como Vandana Shiva (2003), Arturo Escobar (2007), Segato (2007), Quijano (2000; 2005) e Mignolo (2011). Em razão de anteriores estudos a respeito de conflitos possessórios, avizinha-se de produções como as de Bruzaca e Vieira (2017), Bruzaca e Sousa (2018) e Bruzaca (2018).

A aproximação com essas produções se dá em razão de pesquisa referente às ações possessórias envolvendo comunidades rurais negras e latifundiários, com a realização de estudo de caso e análise qualitativa de conteúdo (BRUZACA; VIEIRA, 2017; BRUZACA, 2018). A proximidade metodológica possibilitou a articulação entre referenciais teóricos próximos aos aqui propostos, como o questionamento da constituição de um sujeito de direito geral e abstrato que desconsidera a apreensão de grupos marcados por identidades étnicas e culturais. Ademais, há o alinhamento 
das formas jurídicas usuais da prática em juízo às atividades econômicas empreendidas por grandes proprietários.

Realizaram-se estudos referentes aos conflitos possessórios no contexto urbano, por meio de estudos de caso e análise qualitativa de conteúdo (BRUZACA; SOUSA, 2018), em que também se nota uma relação entre o conteúdo das decisões e o das petições, que estão alinhados aos interesses econômicos de grandes proprietários de terras, não levando em consideração as especificidades dos sujeitos e coletividades presentes no conflito.

\section{DO LEVANTAMENTO PROCESSUAL: REFLEXOS DO CENÁRIO DOS CONFLITOS ENVOLVENDO O AGRONEGÓCIO NO BAIXO PARNAÍBA MARANHENSE}

O destaque ao cenário de conflitos envolvendo o agronegócio no Baixo Parnaíba maranhense contribui para compreender possíveis agravamentos referentes aos impactos territoriais e ambientais em decorrência da utilização de determinados instrumentos processuais, como é o caso das ações possessórias ${ }^{4}$.Tais ações, não raro, configuram a via judicial para a solução do embate territorial entre as comunidades locais e o agronegócio, podendo repercutir na agudização dos referidos conflitos, dependendo do sentido de posse presente na prática jurídica.

Entre os principais empreendedores da região em questão, está a Suzano Papel e Celulose S/A ${ }^{5}$. Data da década de 1980 o início das atividades da referida empresa e da Comercial e Agrícola Paineiras Ltda ${ }^{6}$

4 Em termos gerais, ações possessórias podem ser entendidas no ordenamento jurídico brasileiro como o instrumento do processo civil voltado para a proteção da posse, sendo esta a "situação fática de poder sobre a coisa, pouco importa a condição jurídica de quem a exerce - proprietários ou não proprietários -, afinal a posse recai sobre o bem e não sobre o direito" (FARIAS; ROSENVALD, 2014, p. 56). As ações possessórias são previstas no Capítulo III - Das ações possessórias da Lei n. 13.105/2015, o Código de Processo Civil Brasileiro. Em espécie, são elas a ação de manutenção e de reintegração de posse e o interdito proibitório, que tem como objetivo garantir ao possuidor direto ou indireto a posse, seja mantendo-a, seja reintegrando-a. No juízo possessório, discute-se "posse", sendo os requisitos para sua proteção previstos no art. 561 do Código de Processo Civil, segundo o qual "incumbe ao autor provar: I - a sua posse; II - a turbação ou esbulho praticado pelo réu; III - a data da turbação ou do esbulho; IV - a continuação da posse, embora turbada, na ação de manutenção, ou a perda da posse, na ação de reintegração" (BRASIL, 2015).

5 A Suzano Papel e Celulose S/A é "a segunda maior produtora de celulose de eucalipto do mundo e a maior fabricante de papéis de imprimir e escrever da América Latina”, com sede administrativa em São Paulo, tendo uma das unidades industriais localizada na cidade de Imperatriz, Maranhão. Utiliza-se do discurso do desenvolvimento sustentável ao afirmar que avançam "no objetivo de fornecer produtos e serviços rentáveis e socioambientalmente corretos a partir de [...] florestas renováveis" (SUZANO, 2018).

6 A Comercial e Agrícola Paineiras Ltda é uma das empresas controladas pela Suzano Papel e Celulose S/A, tendo como atividade desenvolvida a de "apoio à produção florestal" (SUZANO, 2016, p. 2-3). 
no leste maranhense, acompanhadas posteriormente, na década de 1990, das atividades de exploração de carvão da Maranhão Gusa S/A e da Maranhão Reflorestadora Ltda. Atualmente, as áreas antes controladas por essas empresas estão sob domínio da empresa Suzano (MARQUES, 2016).

As atividades econômicas empreendidas pela Suzano dizem respeito a atividades de produção em larga escala de bens primários, como é o caso da monocultura de eucalipto. Consequentemente, observa-se a apropriação de grandes quantidades de terra, o que resulta nos conflitos fundiários, possessórios e ambientais que envolvem comunidades tradicionais.

Quantitativamente, é possível fazer um levantamento de ações possessórias, no sistema jurídico eletrônico de buscas do Tribunal de Justiça do Estado do Maranhão, decorrentes da atividade econômica empreendida pela Suzano Papel e Celulose S/A e pela Comercial e Agrícola Paineiras Ltda. Ao se realizar levantamento no Jurisconsult, elencando-se como critério "Consulta Pública - Primeiro Grau - Comarca - Pesquisar pela Parte - Chave de Pesquisa 'Suzano' ou 'Paineiras'”, obteve-se um total de 15 ações possessórias que dizem respeito aos assuntos "Reintegração/ Manutenção de Posse" e "Interdito Proibitório". Dessa maneira, elaborou-se a seguinte tabela:

Tabela 1 Ações possessórias envolvendo as empresas Suzano e Paineiras no Baixo Parnaíba maranhense.

\begin{tabular}{|c|c|c|c|c|c|}
\hline Comarca & N. do processo & Parte & Autor & Réu & Liminar \\
\hline \multirow{13}{*}{ Santa Quitéria } & 6332015 & Suzano & & $\mathrm{X}$ & - \\
\hline & 3632011 & Suzano & & $\mathrm{X}$ & Favorável à comunidade \\
\hline & 1912009 & Suzano & $\mathrm{X}$ & & Favorável à empresa \\
\hline & 5072011 & Paineiras e Suzano & $\mathrm{X}$ & & - \\
\hline & 822005 & Paineiras & $\mathrm{X}$ & & - \\
\hline & 2402005 & Paineiras & $\mathrm{X}$ & & - \\
\hline & 2442005 & Paineiras & $\mathrm{X}$ & & - \\
\hline & 3412009 & $\begin{array}{l}\text { Paineiras e } \\
\text { Claudio Roberto } \\
\text { Martelli }\end{array}$ & $\mathrm{X}$ & & Favorável à empresa \\
\hline & 3422009 & Paineiras & & $\mathrm{X}$ & - \\
\hline & 3342007 & Paineiras & $\mathrm{X}$ & & Favorável à empresa \\
\hline & 522008 & Paineiras & $\mathrm{X}$ & & - \\
\hline & 2122009 & Paineiras & $\mathrm{X}$ & & - \\
\hline & 3352007 & Paineiras & $\mathrm{X}$ & & - \\
\hline \multirow{2}{*}{$\begin{array}{l}\text { Urbano } \\
\text { Santos }\end{array}$} & 7262012 & Paineiras & & $\mathrm{X}$ & - \\
\hline & 10572013 & Paineiras & $\mathrm{X}$ & & Favorável à empresa \\
\hline
\end{tabular}


Nem todos os processos acima elencados envolvem comunidades locais, optando-se por destacar três conflitos com camponeses, todos da Comarca de Santa Quitéria: (i) processo n. 1912009 (numeração única 191 20.2009.8.10.0117); (ii) processo n. 3412009 (341-98.2009.8.10.0117), ambas com decisão liminar favorável à empresa; e (iii) processo n.3632011 (numeração única 363-88.2011.8.10.0117), com decisão liminar favorável à comunidade.

Tais processos, ao decorrerem do cenário de avanço das atividades empreendidas pela Suzano e pela Paineiras, exemplificam a problemática quanto às ações possessórias não somente na microrregião do Baixo Parnaíba maranhense. Assim, aproximam-se aos exemplos em ocorrência em outras localidades maranhenses e brasileiras, em razão de se inserirem no mesmo contexto de conflitos agrários decorrentes de projetos desenvolvimentistas.

Justamente, segundo Augusto et al. (2015, p. 98), o agronegócio é reflexo do modelo agrário decorrente da globalização, no qual se observa um modelo de desenvolvimento ${ }^{7}$ que empreende uma "especialização primária exportadora como projeto hegemônico de acumulação de capital". Continuando, atenta que há uma limitação ao desenvolvimento, acompanhado de situações de ameaça ao meio ambiente, como a expansão do uso de agrotóxicos.

Em sintonia com o marco teórico decolonial, pode-se entender que a associação do agronegócio ao modelo de desenvolvimento repercute na continuidade da dominação decorrente da colonialidade do poder. Segundo Quijano (2000) a colonialidade do poder diz respeito ao padrão de poder mundial capitalista marcado pela classificação da população mundial em raças. Isso resultou, segundo o autor peruano, no eurocentrismo, perspectiva de conhecimento fundada nas necessidades capitalistas de universalidade e nas necessidades do branco de dominar e explorar os demais grupos étnicos, partindo da premissa de sua superioridade, o que incluía conquistar os povos colonizados e impor um espelho que os obrigava a se ver conforme os olhos do dominador.

Em síntese, Mignolo (2011) traz que a colonialidade do poder implica: a (re)classificação hierárquica da população do planeta baseados no marco

\footnotetext{
7 O desenvolvimentismo brasileiro passou por diferentes fases no último século, mas o referido período diz respeito ao nomeado "novo desenvolvimentismo" ou "neodesenvolvimentismo". Neste, observa-se uma reprimarização da economia, com a existência de grandes empreendimentos voltados para a produção de produtos primários, tendo como consequência conflitos com populações locais, como aquelas portadoras de identidades étnicas (SANTOS, 2013). Reforça-se que no cenário do Baixo Parnaíba maranhense, observa-se principalmente o agronegócio, com o monocultivo de eucalipto e soja.
} 
civilizatório, tendo o conceito cultura papel crucial na existência de uma institucionalização para administrar as classificações, influenciando na definição de espaços adequados para as os grupos étnicos classificados; e a canalização da produção de conhecimento baseada nesses ideais. Ainda segundo o citado autor, "o eurocentrismo torna-se, portanto, uma metáfora para descrever a colonialidade do poder".

Desse modo, a Europa tinha o controle do mercado mundial, impondo seu domínio colonial sobre regiões e populações, o que resultou na definição histórica com a atribuição de novas identidades geoculturais a partir do eurocentrismo. Como parte do processo colonial, a Europa teve forte influência na definição sobre a construção do ideal de subjetividade, cultura e produção de conhecimento. Houve a expropriação das populações, a repressão das demais formas de conhecimento, modelos de produção, universos simbólicos e a apreensão da cultura dos dominadores enquanto ideal civilizatório a ser alcançado (QUIJANO, 2005).

Justamente, o agronegócio carrega traços daquela superioridade das maneiras de conhecer e fazer em relação a outras consideradas inferiores. Nesse sentido, para Shiva (2003), o agronegócio repercute em uma uniformidade das monoculturas, em uma maneira de pensar e viver, sendo uma "fonte de escassez e pobreza, tanto por destruir a diversidade e as alternativas quanto por destruir o controle descentralizado dos sistemas de produção e consumo".

Esse desenvolvimentismo que guarda relações com o agronegócio associa-se ao que Segato (2007, p. 45) descreve como aspiração de traço moderno, sendo um conceito importado, como um cargueiro, acarretando em um desenvolvimento por imitação ou mimese. Trata-se da busca pela equiparação a países considerados desenvolvidos, desconsiderando as particularidades e especificidades de sujeitos, grupos, culturas e formas de vidas existentes.

Ademais, o modelo econômico do agronegócio relaciona-se com o discurso do desenvolvimento ${ }^{8}$, associando-se a categorias criadas no âmbito do desenvolvimento rural. Aqui, Escobar (2007) entende existir uma produção da realidade na qual esta é reduzida conforme o conhecimento de especialistas, inexistindo conexão com "determinantes estruturais, muito menos com experiências comuns da população".

8 O discurso do desenvolvimento remete à abordagem utilizada por Escobar (2007) para caracterizar o discurso difundido no final da década de 1950 por Truman, ex-presidente dos Estados Unidos, no qual transforma a realidade de países e populações ao criar a realidade de países ansiosos pela equiparação aos países considerados de primeiro mundo, resultando na desconsideração daquela realidade. 
Especificamente quanto ao choque existente no Baixo Parnaíba maranhense, a luta pela terra pelos camponeses remete à autonomia do seu lugar social, que é ameaçada pela empresa Suzano Papel e Celulose S/A, cujas práticas resultam em danos ao ambiente e ao território, com a morte de animais e perda da vegetação nativa. A importância da terra é percebida por fazer parte da economia familiar, servindo para a existência do próprio grupo social (RIBEIRO JÚNIOR; OLIVEIRA; COSTA, 2014).

Se por um lado, no agronegócio a relação entre homem e natureza media-se pelo mercado e pelo negócio, por outro a sociobiodiversidade cultural é observada "nos povos que produzem alimento, vivem na terra e da terra, das águas e da floresta" (AUGUSTO et al., 2015). Com isso, a posse exercida por comunidades de um lado, e pelas empresas de outro, mostram-se conflitantes.

Assim, a análise que se segue é praticada sobre as práticas jurídicas, que podem repercutir ou não na proteção do território e do meio ambiente, quando próximas à tutela dos direitos da comunidade, ou na continuidade da monocultura, do uso de agrotóxicos e da apropriação territorial pelas.

\section{DAS AÇÕES POSSESSÓRIAS: SOBRE OS CONFLITOS ENVOLVENDO A SUZANO PAPEL E CELULOSE E DA COMERCIAL AGRÍCOLA PAINEIRAS}

\subsection{Processo n. 191/2009 (numeração única 191-20.2009.8.10.0117)}

Trata-se de ação de reintegração de posse ajuizada pela Suzano Papel e Celulose S/A em face de Francisca, líder comunitária do povoado Baixão da Coceira, e Sebastião, líder comunitário do povoado Coceira. $\mathrm{Na}$ inicial, apresenta a "desnecessidade de identificação e da qualificação dos réus/invasores" nos "casos de invasão coletiva", amparando-se jurisprudencialmente. Seguindo, comprova-se a posse da parte autora com "contrato de arrendamento [...], certidões de matriculas, escrituras e memoriais descritivos, certidões, certificados de cadastros de imóveis rurais [...], e mapas" (SUZANO, 2009a).

Ademais, detalha que, entre as áreas apresentadas, algumas correspondem a fazendas que pertenciam à Margusa S/A e Marflora Ltda, nas quais se "exerciam [...] atividades econômicas de extração de madeira e reflorestamento, desde os anos de 1989 e 1990". Atenta que na localidade existem campos de cultivo de eucalipto, casas de alvenaria e manutenção 
de marcos, divisas e vigilância. Entretanto, afirma que os réus "lideraram invasão violenta de aproximadamente 50 pessoas, moradores dos povoados Baixão da Coceira e Coceira [...] e paralisaram serviço de supressão de vegetação, autorizado pela SEMA [Secretaria de Meio Ambiente]" (SUZANO, 2009a).

Adiante, apresenta pedido liminar de reintegração de posse, com base no art. 928 do Código de Processo Civil de $1973^{9}$, vigente à época e que corresponde ao atual art. 562 do Código de Processo Civil. Afirma pela existência de "todos os requisitos necessários à concessão de liminar, quais sejam, a existência da posse, a moléstia sofrida na posse e a data em que tal tenha ocorrido". Novamente, fundamenta a comprovação da posse em razão da aquisição por negócio jurídico, com manutenção da anterior "ingerência socioeconômica mansa e pacífica", além da existência de atividades florestais. Já o esbulho, com menos de um ano e um dia, busca comprovar pelas certidões de ocorrência policial. Por fim, expõe que a medida é de urgência tendo em vista que a "invasão ilegal" pode "causar grave precedente de instabilidade social e insegurança jurídica na região" (SUZANO, 2009a).

Liminarmente, o juízo decidiu:

Nos termos do art. 928 do Código de Processo Civil [de 1973], e em razão dos argumentos expostos e documentos atrelados na petição inicial, em particular os de fls. [sic], verifico que são verossímeis e plausíveis, numa primeira análise, os fatos alegados pela empresa requerente, consistentes na injusta privação da posse de um bem que lhe pertence, o que a primeira vista está documentado através de Contrato de Afloramento (fls.) [sic], Escritura Pública de Compra e Venda, comprobatório da propriedade do imóvel, estando assim presente o requisito do fumus boni iuris (fumaça do bom direito).

Defiro, pois, sem ouvir o requerido, a medida liminar de reintegração de posse, em decorrência do esbulho noticiado [...] (MARANHÃO, 2009a).

Desse modo, o juízo decidiu liminarmente pela reintegração da posse, entendendo pela comprovação de invasão ilegal sobre a propriedade da empresa por meio dos documentos apresentados pela parte autora. Ressalte-se, ainda, que a liminar foi concedida sem que a parte contrária tenha sido ouvida, ou seja, sem a realização da audiência de justificação prevista na segunda parte do art. 928 do Código de Processo Civil de 1973.

Com isso, confirma-se a tutela de uma posse fundamentada em títulos

9 Art. 928, Código de Processo Civil de 1973 - estando a petição inicial devidamente instruída, o juiz deferirá, sem ouvir o réu, a expedição do mandado liminar de manutenção ou de reintegração; no caso contrário, determinará que o autor justifiquepreviamente o alegado, citando-se o réu para comparecer à audiência que for designada (BRASIL, 1973, grifos nossos). 
de propriedade e documentos formais, que possibilitam a continuidade das atividades econômicas empreendidas pela parte autora. Entende-se que o termo posse acaba, nesse caso, se alinhando às práticas dos empreendedores do agronegócio, reproduzindo concepções de desenvolvimento, afetando o desenho do território e impactando o meio ambiente.

Na presente ação, a comunidade foi representada juridicamente pela Sociedade Maranhense de Direitos Humanos. Visando a reconsideração da liminar e o julgamento improcedente da ação, de início sustenta-se na contestação de que o pedido apresentado é juridicamente impossível, tendo em vista a ausência de comprovação da posse, mas, sim, da propriedade. Assim, apresenta que "todos os requisitos acostados nesta peça contestatória e suas famílias exercem legitimamente a posse daquelas terras há pelo menos um século" (SMDH, 2009a).

Adiante, apresenta a caracterização da posse exercida pelas comunidades de Baixão da Coceira, Coceira e Lagoa das Caraíbas. Nesse sentido, destaca que:

Essas famílias residem e laboram naquela área há, pelo menos, três gerações, vivendo exclusivamente da agricultura familiar, criação de pequenos animais e extrativismo vegetal, principalmente do bacuri e do pequi, espécies típicas da região. Contudo, com a expansão desenfreada da monocultura de soja e de eucalipto na região, já não se encontram com muita facilidade essas espécies, prejudicando sobremaneira a complementaridade do ciclo produtivo dessas famílias (SMDH, 2009a).

Contextualiza o conflito, resgatando o cenário da década de 1980 da região, marcado pela expansão da monocultura do eucalipto e do sustento de atividades siderúrgicas, provocando graves impactos socioambientais. Com isso, atenta que frente a tais atividades existem denúncias e resistências por parte das comunidades, além de tentativas de regularização fundiária das terras pelo Instituto Nacional de Colonização e Reforma Agrária e pelo Instituto de Terras do Maranhão, que inclusive resulta no questionamento da legalidade dos títulos das empresas (SMDH, 2009a).

Ainda na contestação, observa-se a temática da função social da propriedade, pontuando que, com a Constituição da República Federativa do Brasil de 1988, aquela perde seu caráter absoluto. Reitera que as comunidades utilizam a área por gerações, para fins de subsistência, com o extrativismo do pequi e do bacuri. Conclui, portanto, que quem cumpre a função social da propriedade são os membros da comunidade, não a empresa, merecendo assim a tutela possessória (SMDH, 2009a).

Por fim, questiona o licenciamento ambiental das atividades 
empreendidas pela Suzano Papele Celulose S/A, atentando pela inexistência de estudo prévio de impacto ambiental. Inclusive, apresenta que, à época, as atividades dessas empresas foram investigadas pelo Ministério Público Federal no Maranhão e no Piauí (Procedimento Administrativo n. 1.19.000.001472/2007-37). Quanto às licenças expedidas pela Secretaria de Meio Ambiente, além de entender serem eivadas de ilegalidade, resultam na "expurga[ção] de terras tradicionalmente laboradas [pelos] trabalhadores que nasceram e se criaram nessas comunidades" (SMDH, 2009a).

Desse modo, observa-se outro sentido à concepção de posse, quando observado pelo ponto de vista da comunidade. Trata-se da utilização de instrumentos processuais com a finalidade de manter as relações sociais, econômicas e ambientais existentes há gerações pelos membros da comunidade, como com a continuidade das atividades extrativistas e com a manutenção das famílias na terra.

Em razão da decisão liminar, a SMDH ainda interpôs agravo de instrumento. Nele existem fundamentos semelhantes ao da contestação, principalmente no que diz respeito à caracterização da posse, deslegitimando a da empresa e sustentando a da comunidade. Novamente se destaca a questão da função social da propriedade e do conflito socioambiental que envolve a empresa e a comunidade. Ademais, ainda afirma pela nulidade dos atos em razão da ausência de intervenção do Ministério Público Federal, fundamentada no art. 82 da Constituição da República Federativa do Brasil de $1988^{10}$ (SMDH, 2009b).

No juízo de retratação, decidiu-se pela revogação da liminar e indeferimento da petição inicial. Para tal, afirma-se que "não pode esta Magistrada, analisar o pedido de 'reforço' da liminar sem tomar conhecimento de todos os documentos existentes nos autos, como é de hábito". Afirma, adiante, que "não há como atender ao pedido por inteira falta de representação processual da autora e sua signatária" (MARANHÃO, 2009c) - essa decisão foi proferida por uma magistrada diferente da primeira.

Dessa decisão, a empresa apresentou o recurso de apelação, sustentando principalmente questões do direito processual civil referente à representação jurídica, mas reafirmando a posse mansa e pacífica pela 10 Art. 82, Constituição da República Federativa do Brasil de 1988 - Compete ao Ministério Público intervir:

$[\ldots]$

III - nas ações que envolvam litígios coletivos pela posse da terra rural e nas demais causas em que há interesse público evidenciado pela natureza da lide ou qualidade da parte (BRASIL, 1988). 
empresa (SUZANO, 2009b). Em seguida, o juízo novamente determina a continuação da posse (MARANHÃO, 2010a) - trata-se de uma decisão proferida por um terceiro magistrado, diferente das anteriores. No último ato processual até então consultado, uma quarta magistrada decide por tornar sem efeito esta última decisão, mas dá continuidade à ação, com a necessidade de reapreciação da liminar (MARANHÃO, 2010b).

\section{Assim, destaca-se:}

[...] em relação à liminar solicitada na petição inicial, o caso é de reapreciação dela, e assim o faço com base no pedido do Ouvidor Agrário Nacional e Presidente da Comissão Nacional de Combate à Violência no Campo de fl. 682 e no Provimento n. 29/2009 da Corregedoria Geral de Justiça (MARANHÃO, 2010b).

Apesar do processo ainda não ser finalizado, o conflito exemplifica as práticas jurídicas diferenciadas existentes na advocacia tradicional e popular, bem como no judiciário. Importante notar as estratégias existentes para a manutenção das comunidades na terra, que rompem com uma visão formalista do direito de posse e propriedade; além da existência de vias elaboradas pelo Estado de tutela daqueles grupos quanto à violência no campo, a exemplo do Provimento n. 29/2009 da Corregedoria Geral de Justiça ${ }^{11}$.

\subsection{Processo n. 341/2009 (numeração única 341-98.2009.8.10.0117)}

\section{O próximo processo judicial a ser analisado diz respeito a ação de}

11 O referido provimento "Dispõe sobre recomendação aos(às) Juízes(as) de Direito do Estado do Maranhão para que ouçam o Ministério Público do Maranhão, a Ouvidoria Agrária Nacional, o INCRA e o ITERMA em ações de manutenção e reintegração de posse coletiva envolvendo imóveis rurais ocupados por trabalhadores rurais sem-terra" (MARANHÃO, 2009b).

Nele se recomenda: 1) "Antes de decidirem pedidos de liminar, notifiquem o Ministério Público do Maranhão, a Ouvidoria Agrária Nacional, o INCRA e o ITERMA, tendo em vista que essa providência, além de facilitar a execução do Plano Nacional de Reforma Agrária no Estado do Maranhão, viabilizará o fornecimento de elementos que permitirão uma melhor análise e investigação a respeito das questões fundiárias levadas a Juízo, evitando-se que o Judiciário dê provimento a pretensões fundadas em escrituras públicas e títulos não idôneos" e; 2) "Em casos de concessão de liminares e de procedência dos pedidos, determinem, para o cumprimento do decisum, a intimação dos Órgãos e Entes relacionados no item n. 1 (um) deste Provimento, bem como que os oficiais de justiça e a Polícia Militar cumpram, tanto quanto possível, o Manual de Diretrizes Nacionais Para Execução de Mandados Judiciais de Manutenção e Reintegração de Posse Coletiva, elaborado pela Ouvidoria Agrária Nacional e aprovado pelos Comandantes-Gerais das Polícias Militares, em reunião realizada em Brasília, na sede da Ouvidoria Agrária Nacional, no dia 11 de abril de 2008, tendo em vista, em especial, a possibilidade de a Ouvidoria providenciar os meios necessários para facilitar a desocupação pacífica do imóvel rural objeto da lide possessória, tais como o fornecimento de cestas de alimentos, fornecimento de lonas para montagem de novo acampamento, transporte para fazer a mudança dos requeridos e gestão junto ao INCRA para vistoriar outro imóvel rural com a finalidade de assentá-los, o que viabilizará a desocupação pacífica da área em discussão, garantindo efetividade à decisão judicial" (MARANHÃO, 2009b, grifos nossos). 
manutenção de posse ajuizada pela Comercial e Agrícola Paineiras Ltda. em face da liderança comunitária Francisco das Chagas Sousa Amorim ${ }^{12}$. $\mathrm{Na}$ inicial, afirma que a empresa pertence à Suzano Papel e Celulose S/A, que atua no Maranhão há 26 anos, "com missão institucional de pesquisar e desenvolver variedades de eucalipto adaptadas aos solos arenosos e clima seco". Adiante, comprova a propriedade da empresa das áreas com documentos oficiais, além de afirmar cumprir as exigências ambientais necessárias às atividades e as decorrentes da condição de possuidora dos imóveis. Assim, afirma que "todos estes são fatos que tornam evidente a posse da autora" (PAINEIRAS, 2009).

Assim como na ação anteriormente descrita, fundamenta a caracterização da posse com documentos oficiais ao afirmar que a parte autora é "legítima possuída dos imóveis objeto da presente ação, o que é corroborado pelos documentos". Também amparado pelo art. 928 do Código de Processo Civil de 1973, solicita liminar de reintegração de posse, afirmando pelo preenchimento de todos os requisitos processuais (PAINEIRAS, 2009).

Diferente da ação anterior, houve audiência de justificação. Entretanto a parte contrária não compareceu. Nela, decidiu-se que:

[...] o caso é de deferimento da medida liminar pleiteada, pois, in casu, estão presentes seus pressupostos autorizadores. Como é cediço, para a concessão de medida liminar, torna-se necessária a presença de dois requisitos, quais sejam, o fumus boni júris e o periculum in mora. O fumus boni júris, ou "fumaça do bom direito", é requisito que, quando presente, enseja uma presunção de legitimidade do pleito inicial, ou seja, evidencia uma verossimilhança da alegação do autor. No caso vertente, a Requerente conseguiu demonstrá-lo, pois o autor junto aos autos documentos de propriedade das áreas (fls. 35/88), com fotos (fls. 99/102) e boletim de ocorrência policial (fl. 98) [...] (MARANHÃO, 2011a, grifos nossos).

Assim, na decisão liminar observa-se que a comprovação da propriedade reforça a caracterização da posse pela parte autora. Em outros termos, reconhece-se, por meio de documentos oficiais, além da menção a fotos e a testemunhas, o exercício de fato sobre o imóvel, sem considerar a existência de outras práticas sociais na localidade. Assim, ampara juridicamente a empresa para dar continuidade ao exercício de suas atividades econômicas em contraposição às resistências empreendidas pela população local.

12 À primeira vista, observa-se que se trataria de um conflito individual, mas destaca-se que a parte contrária, ou seja, Francisco das Chagas Sousa Amorim, conhecido como Seu Chagas, é liderança da comunidade de Lagoa das Caraíbas, razão pela qual o processo manteve-se como objeto do presente artigo científico. 
Nessa mesma ação, a liderança comunitária de Lagoa das Caraíbas é ainda acusada de degradação ambiental, o que também exemplifica a dissonância entre as práticas comunitárias e empresariais na região. Afirma-se que "o Réu, Francisco das Chagas Sousa Amorim, está promovendo nova turbação na área objeto da presente [comunidade], através de desmatamento e retirada de madeira, de forma violenta e clandestina, sem licença ambiental, em uma área de aproximadamente 50ha (cinquenta hectares), conforme fotos e boletim de ocorrência anexos" (PAINEIRAS, 2013). Enquanto as atividades econômicas da empresa que, conforme fora destacada na ação anterior pela Sociedade Maranhense de Direitos Humanos, repercute em graves conflitos socioambientais, aqui se sustenta a criminalização da liderança em razão do extrativismo de madeira.

$\mathrm{Na}$ contestação, há o questionamento dos documentos apresentados pela parte autora, com a existência de informações conflitantes quanto ao registro presentes nesses documentos. Com isso, apresenta-se que as informações ora trazidas são "capazes de solucionar a presente demanda com memoriais precisos, plantas planimétricas e outros bens elucidativos". Seguindo, reitera que "a autora apenas cita que possui os citados imóveis porém não junta outros documentos que possibilite[m] a exatidão do ora afirmado" (CONTESTAÇÃO, 2014).

A presente ação foi julgada extinta sem resolução do mérito (MARANHÃO, 2018a). Não obstante, importante notar que diferente da atuação da assessoria jurídica da Sociedade Maranhense de Direitos Humanos, não se observa nessa defesa qualquer menção à caracterização da posse por membros da comunidade, a inserção da lide no cenário conflituoso com a empresa na região, nem ao cumprimento da função social. A prática jurídica descrita resumiu-se no questionamento dos documentos apresentados pela parte autora, sem sequer mencionar que não é na sede das ações possessórias que se debate propriedade.

\subsection{Processo n. 363/2011 (numeração única 363-88.2011.8.10.0117)}

A presente ação de interdito proibitório foi ajuizada pela Sociedade Maranhense de Direitos Humanos em favor de membros da comunidade Bracinho, em face da empresa Suzano Papel e Celulose Ltda. Caracteriza Bracinho na petição inicial como comunidade tradicional, afirmando-se que "relatam que nasceram e se criaram naquelas terras, convivendo de modo pacífico e harmonioso com o ambiente local" (SMDH, 2011). 
Resgata o histórico da comunidade em buscar a regularização fundiária da área pelo Instituto de Terras do Maranhão. Destaca-se o início dos conflitos envolvendo o agronegócio na região do Baixo Parnaíba maranhense, com descrição das resistências empreendidas pela comunidade contra a empresa. Reforça os impactos socioambientais provocados pelo monocultivo do eucalipto na região (SMDH, 2011).

Quanto à caracterização da posse pela comunidade, destaca que "é exercida não apenas pelos requerentes e demais membros das comunidades, mas também por seus ancestrais", identificando-os como "posseiros", fundamentando a proteção possessória com o art. 932 do Código de Processo Civil de $1973^{13}$ - atual art. 567 do Código de Processo Civil de 2015. Ainda faz menção à função social da propriedade, cumprida pelos membros da comunidade (SMDH, 2011).

Seguindo, traz ainda o descumprimento da Convenção n. 169 da Organização Internacional do Trabalho quanto ao respeito dos direitos territoriais de povos e comunidades tradicionais e à consulta das atividades econômicas empreendidas pela empresa na região. Por fim, sustenta ainda o cumprimento dos requisitos para a concessão do pedido liminar, ou seja, o fumus boni júris e o periculum in mora (SMDH, 2011).

É possível identificar, nesta oportunidade, que a assessoria jurídica da Sociedade Maranhense de Direitos Humanos não resume sua prática a uma concepção pura e simplesmente formalista dos conflitos. A tutela possessória não se resume a debater a legalidade ou legitimidade de documentos oficiais, mas sim arranjos sociais que estabelecem a comunidade enquanto tradicional, a relação com a natureza, bem com outros direitos que fogem ao caráter individual e liberal do debate possessório, ou seja, o direito ao território e ao meio ambiente.

O juízo concedeu o pedido liminar, afirmando:

Comprovação da posse dos autores (lavradores) faz-se com as declarações de fls. 21/111, bem como pelos documentos de fls. 119/124, estes últimos comprovam a existência do Processo n. 1.254/2010 perante o ITERMA, cujo objeto é a regularização da área do Povoado Bracinho, Município de Santa Quitéria/MA, assim como as fotos de fls. 125/129 que retratam as benfeitorias e moradores da comunidade do Povoado Bracinho, Santa Quitéria/MA.

Já a comprovação da iminência de turbação ou esbulho da área de posse e da continuação desta faz-se pela Certidão Policial de fl. 35.

13 Art. 932, Código de Processo Civil de 1973. O possuidor direto ou indireto, que tenha justo receio de ser molestado na posse, poderá impetrar ao juiz que o segure da turbação ou esbulho iminente, mediante mandado proibitório, em que comine ao réu determinada pena pecuniária, caso transgrida o preceito (BRASIL, 1973). 
Já o periculum in mora pode ser fundamentado no fato de que os Requerentes são moradores e trabalhadores da área em questão se esta área for desmatada, envenenada e/ou invadida pela Requerida os Requerentes sofrerão sérios prejuízos no modo de viver, pois poderão ficar sem moradia, sem área para a roça e sem plantas para praticarem o extrativismo.

Além disso, o desmatamento gera um grave prejuízo ambiental, irreversível, até porque além do desmatamento se é jogado veneno na terra, o que ocasiona desaparecimento de fauna e flora da Região e aumenta o grau de calor já sentido no Baixo Parnaíba, o que poderá abalar sensivelmente a Comunidade formada pelos Requerentes, pessoas de parcos poderes aquisitivos e que dependem da natureza para sobreviver, até porque muitos dos Requerentes vivem única e exclusivamente de roça e extrativismo, além da pesca artesanal nos rios e lagos da Comunidade (MARANHÃO, 2011b, grifos nossos).

Observa-se que nessa ação a prática do judiciário modifica-se, resgatando questões que antes eram desconsideradas, como a condição da comunidade enquanto coletividade, os impactos sobre o modo de vida, a moradia e a economia. Assim, a posse é entendida como aquela alinhada às práticas de comunidades, não se resumindo a uma concepção formalista e fundamentada na propriedade. Com isso, reforça o contraponto àquela prática que possibilita a continuidade das atividades do agronegócio ao pôr em debate os referidos aspectos sociais, ambientais e econômicos do conflito.

Disto se extrai da peça de contestação apresentada pela empresa. Afirma-se que os membros da comunidade não são parte legítima em razão da área ser de domínio do Estado, sendo deste a posse. Ademais, que esse procedimento administrativo tem como parte a Associação Comunitária Gabriel Alves de Araújo, considerando esta detentora dos direitos pleiteados (SUZANO, 2012a).

Seguindo, afirma que os autores não são possuidores, pois "a verdadeira proprietária e possuidora indireta da maior parte destas terras é, e sempre foi, a empresa Comercial e Agrícola Paineiras Ltda (doc. 07/18), e a possuidora direta é a Suzano Papel e Celulose S/A". Apresenta que as áreas foram adquiridas pela empresa desde a década de 1980 e que existem plantios de eucalipto com as devidas licenças ambientais (SUZANO, 2012a). Questionando a decisão liminar, interpôs agravo de instrumento. Com argumentos semelhantes à contestação (SUZANO, 2012b). Assim, nas peças apresentadas pelos representantes jurídicos da empresa observa-se novamente a fundamentação na propriedade para a proteção da posse desta. Não há vasto debate a respeito daquelas outras questões de aspecto 
social, econômico e ambiental, preponderando o argumento formal, facilitando a continuidade das atividades do agronegócio.

Em decorrência de despacho nos autos daquele agravo de instrumento (n. 7987/2012), proferido pelo juiz de segunda instancia, o juiz originário apresenta o motivo pelo qual concedeu a medida liminar. Nela, destaca a narração do conflito pela comunidade, os perigos socioambientais decorrentes do agronegócio, os problemas fundiários decorrentes da grilagem de terras e os prejuízos causados às comunidades tradicionais (MARANHÃO, 2012a).

Em segunda instância, negou-se provimento ao recurso, com a seguinte ementa:

AGRAVO DE INSTRUMENTO. AÇÃO DE INTERDITO PROIBITÓRIO. REQUISITOS PRESENTES PARA A CONCESSÃO DE LIMINAR.

I - Evidenciada a posse dos autores, ora recorridos, e o seu justo receio de nela serem molestados pelo Réu Agravante, presentes estão os requisitos do art. 932 do CPC, não havendo, pois, reparos a fazer na decisão insurgida.

II - Ainda que público seja o imóvel objeto do litígio, forçoso é convir que a sua ocupação pelos recorridos, no decurso de longo tempo, corrobora para que se mantenha provisoriamente, a situação atual, até final julgamento da ação, máxime quando se cogita a possibilidade de desmatamento pela outra parte (MARANHÃO, 2012b, grifos nossos).

Portanto, confirma-se em segunda instância a decisão favorável à comunidade, novamente resgatando os debates relevantes para o conflito, como os referentes aos conflitos socioambientais existentes. Há ainda réplica por parte da comunidade, destacando-se o equívoco ao considerar que as terras ocupadas pela comunidade são do Estado do Maranhão, reiterando que os membros daquela são possuidores da área. Vale ressaltar que os 21 requerentes são legítimos para a ação possessória, bem como que o território é de posse da comunidade e que "não se configura apenas com a construção de benfeitorias", havendo ainda respeito à vegetação nativa $\mathrm{e}$ à preservação do meio ambiente (SMDH, 2012).

Aqui, junta-se ao processo o relatório de pesquisa "Conflitos Socioambientais no leste maranhense: problemas enfrentados pela atuação da Suzano Papel e Celulose e dos chamados gaúchos no Baixo Parnaíba", de autoria do Grupo de Estudos Rurais e Urbanos da Universidade Federal do Maranhão (SMDH, 2012). Por fim, destaca-se a existência de pedido de intervenção por parte do Instituto de Terras do Maranhão (MARANHÃO, 2018b). 
Em resumo, na presente ação, observa-se a prática jurídica da advocacia popular e do judiciário, em primeira e segunda instância, em favor do reconhecimento da posse pela comunidade. Para tal, não há fundamentação em documentos oficiais que comprovem a propriedade, mas sim da situação fática baseada na condição da comunidade enquanto população tradicional, que mantém uma relação harmônica com a natureza e desenvolve atividades para a subsistência.

\section{ANÁLISE QUALITATIVA DE CONTEÚDO E ANÁLISE GLOBAL}

Após a descrição pormenorizada das ações possessórias envolvendo as empresas Suzano e Paineiras, empreendida no tópico anterior, agora passa-se ao exame do caso conforme a análise qualitativa de conteúdo. Assim, procede-se à análise explicativa do conteúdo, de acordo com a "síntese de análise de conteúdo", parafraseando-se o material, e obtendo como resultado a "redução do material por meio da omissão de enunciados incluídos em uma generalização" (FLICK, 2009, p. 291-293).

Nesse sentido, aos advogados representantes das empresas, destacam-se em síntese as seguintes práticas jurídicas: (i) equiparação a casos de invasões coletivas; (ii) comprovação da posse com documentos de propriedade e em negócio jurídico; (iii) importância às atividades econômicas do agronegócio; (iv) criminalização de moradores; (v) comprovação do esbulho por meio de ocorrência policial.

No que diz respeito aos assessores jurídicos da comunidade, com ênfase na advocacia popular em representação feita pela $\mathrm{SMDH}$, sintetiza-se a prática jurídica da seguinte maneira: (i) impossibilidade de comprovação da posse com documentos de propriedade e em negócio jurídico; (ii) comprovação da posse pela secular ocupação da área pela comunidade; (iii) trabalho na terra com base na economia familiar; (iv) contextualização dos conflitos envolvendo o agronegócio; (v) cumprimento da função social da propriedade; (vi) descumprimento da Convenção n. 169 da Organização Internacional do Trabalho.

Quanto ao judiciário nas decisões em favor da empresa, a prática é sintetizada pelo reconhecimento da posse por documentos de propriedade e em negócio jurídico. Em favor da comunidade: (i) reconhecimento da posse pelo uso de fato da terra; (ii) proteção da forma de vida da comunidade; (iii) impossibilidade de comprovar posse por meio de documentos de propriedade e em negócio jurídico. 
Primeiramente, quanto às práticas jurídicas alinhadas aos interesses do agronegócio, destacam-se as práticas de (i) equiparação a casos de invasões coletivas, (ii) comprovação da posse com documentos de propriedade e em negócio jurídico e (iii) comprovação do esbulho por meio de ocorrência policial; são os argumentos utilizados pelo representante da empresa. $\mathrm{O}$ judiciário por vezes decide pelo reconhecimento da posse por documentos de propriedade e em negócio jurídico.

Entende-se que tal prática, não raramente observada nas ações possessórias envolvendo coletividades, como se observa no presente estudo de caso, repercute na manutenção da perspectiva individualista de direitos. Aproxima-se à formação dos atores jurídicos denunciada por Aguiar (1994, p. 20), sendo ela general, superficial, periférica, normativista e textualiza, que "não reproduz um conhecimento contextual operatório, que dê conta juridicamente dos novos fatos, atos e fenômenos que emergem da sociedade".

Especificamente quanto aos conflitos possessórios, destacam-se dois estudos a respeito dessa temática no Maranhão. O primeiro no contexto urbano, no qual se verifica conflitos entre comunidades e agentes econômicos que empreendem atividades baseadas na especulação imobiliária, sendo a posse por vezes considerada apenas sob o aspecto formal e comprovada por títulos de propriedade, desconsiderando as relações sociais e econômicas empreendidas pelos ocupantes (BRUZACA; SOUSA, 2018).

O segundo diz respeito aos conflitos possessórios envolvendo comunidades quilombolas, também na região do Baixo Paranaíba maranhense, em que a análise dos conflitos é por vezes resumida a questões processuais formais, sem levar em consideração a complexidade das relações territoriais empreendidas pelas comunidades (cf. BRUZACA, 2018). Aqui, apesar de se tratarem de grupos étnicos com direitos reconhecidos nacional e internacionalmente, também prepondera aquela visão normativista e textualista que desconsidera a realidade específica da região e a relação de subsistência dessas populações no que tange ao meio ambiente.

Assim, retornando ao caso, nas práticas favoráveis à apropriação territorial das referidas empresas, a posse, mais uma vez, resume-se a uma concepção formal, comprovada com o documento da propriedade da terra. A decisão repercute na inobservância da previsão constitucional quanto ao cumprimento da função social e ambiental da propriedade (art. $5^{\circ}, \mathrm{XXIII}^{14}$, e

14 Art. $5^{\circ}$, XXIII, Constituição da República Federativa do Brasil de 1988 - A propriedade atenderá a sua função social (BRASIL, 1988). 
art. 170, III ${ }^{15}$ ), que ocorre com o uso racional da terra, dos recursos naturais e do ambiente, além da observância às relações de trabalho e promoção do bem-estar dos proprietários e trabalhadores (art. 186 ${ }^{16}$ ) (BRASIL, 1988).

A respeito das disputas pela posse, uso e distribuição de terra, Wolkmer (2001, p. 106) destaca que estão inseridas em uma estrutura agrária de privilégios e injustiças - o que se alinha àquela primeira concepção. Com isso, entende o referido autor que há uma produção da legalidade comprometida com os interesses das elites tradicionais.

Justamente, como atentam Bruzaca e Vieira (2017, p. 193), a compreensão dos termos jurídicos existentes nas ações possessórias, como sujeitos, proprietários, possuidores, detentores remetem a abstrações, cujos sentidos podem se alinhar àquela ideologia liberal-individualista. Trata-se de crítica pontuada por Miaille (2005, p. 49), face ao idealismo jurídico, para quem existe uma produção de ideias para apropriação dos fenômenos, em contrapartida às várias maneiras de pensar.

Quanto à importância das atividades econômicas do agronegócio, entende-se pela presença do discurso desenvolvimentista na prática jurídica, trazendo-se argumentos não jurídicos em favor da empresa. Como destacado anteriormente, tal modelo de desenvolvimento associa-se à colonialidade do poder, considerando determinadas raças, culturas, formas de vida e conhecimento inferiores àquelas empreendidas pelo capitalismo mundial (QUIJANO, 2000; 2005), o que justificaria sua inferior relevância em relação aos interesses econômicos. Enquanto a importância do agronegócio é demonstrada em juízo por meio de números, os modos de vida das comunidades são desconsiderados e, além disso, essa perspectiva é baseada na criminalização de moradores, seja por considerá-los invasores, seja por acusá-los de degradar o meio ambiente.

Com relação às práticas jurídicas das ações possessórias, estas fomentam a impossibilidade de comprovação da posse com documentos de propriedade e em negócio jurídico, valendo-se da comprovação da posse

15 Art. 170, Constituição da República Federativa do Brasil de 1988 - A ordem econômica, fundada na valorização do trabalho humano e na livre iniciativa, tem por fim assegurar a todos existência digna, conforme os ditames da justiça social, observados os seguintes princípios:

$[\ldots]$

III - função social da propriedade (BRASIL, 1988).

16 Art. 186, Constituição da República Federativa do Brasil de 1988 - A função social é cumprida quando a propriedade rural atende, simultaneamente, segundo critérios e graus de exigência estabelecidos em lei, aos seguintes requisitos:

I - aproveitamento racional e adequado;

II - utilização adequada dos recursos naturais disponíveis e preservação do meio ambiente;

III - observância das disposições que regulam as relações de trabalho;

IV - exploração que favoreça o bem-estar dos proprietários e dos trabalhadores (BRASIL, 1988). 
pela secular ocupação da área pela comunidade e pelo cumprimento da função social da propriedade. O que se observa aqui é que a advocacia popular visa à passagem de um modelo de base individualista para outro baseado na politização e coletivização do direito (SANTOS, 2011, p. 65). Em consequência a essa prática, o judiciário posiciona-se pelo reconhecimento da posse pelo uso de fato da terra e pela proteção da forma de vida da comunidade.

Seguindo, a contextualização dos conflitos envolvendo o agronegócio repercute no reconhecimento dos impactos sobre os direitos das populações afetadas pelos grandes empreendimentos econômicos. Associa-se assim às resistências ao modelo de desenvolvimento alinhado ao agronegócio, bem como à superação da colonialidade implicada nesse modelo. Nesse sentido, observa-se também a importância dada ao trabalho na terra com base na economia familiar.

Em outras palavras, visualiza-se a existência de uma prática jurídica que reconhece a importância dos modos de vida das comunidades rurais, não as considerando inferiores ao modelo de desenvolvimento associado ao agronegócio. Conforme alerta Quijano (2000), nenhuma alternativa ao desenvolvimento imposto pelo padrão de poder capitalista moderno e colonial é possível caso se perdure a "des-democratização contínua das relações sociais", a "polarização social" e a "imiseração de cada vez maiores proporções da população". Reconhecer a relevância da produção e cultura de grupos subalternizados é se contrapor àquele desenvolvimento.

Destaca-se o descumprimento da Convenção n. 169 da OIT, trazendo ao debate normas internacionais que tratam de direitos das comunidades afetadas. Segundo Shiraishi Neto (2007), o reconhecimento desses direitos implica:(i) o deslocamento das disciplinas tradicionais; (ii) a relativização e reorganização da hierarquia de normas; (iii) reafirmação e ampliação de normas de proteção de direitos humanos. Trata-se novamente de uma contraposição à prática jurídica que sustenta as práticas do agronegócio e, consequentemente, fortalece alternativas ao modo de desenvolvimento que este propõe.

Por fim, passada a contextualização dos conflitos, a descrição das ações possessórias e a análise qualitativa do material é possível, de maneira suplementar à elaboração da análise global. Essa análise, conforme destaca Flack (2009), consiste na produção de uma tabela com conteúdos do texto, palavras-chave e temas. Assim, seguindo as paráfrases destacadas neste tópico, produziu-se a seguinte tabela: 
Tabela 2 Análise global

\begin{tabular}{|c|c|c|c|}
\hline Temas & $\begin{array}{l}\text { Advocacia alinhada aos } \\
\text { interesses da empresa }\end{array}$ & $\begin{array}{l}\text { Advocacia em defesa } \\
\text { dos direitos das } \\
\text { comunidades }\end{array}$ & Judiciário \\
\hline Posse & $\begin{array}{l}\text { Comprovação da posse } \\
\text { com documentos de } \\
\text { propriedade e em } \\
\text { negócio jurídico. }\end{array}$ & $\begin{array}{l}\text { Impossibilidade de } \\
\text { comprovação da posse } \\
\text { com documentos de } \\
\text { propriedade e em } \\
\text { negócio jurídico; } \\
\text { Comprovação da posse } \\
\text { pela secular ocupação da } \\
\text { área pela comunidade. }\end{array}$ & $\begin{array}{l}\text { Reconhecimento da } \\
\text { posse por documentos } \\
\text { de propriedade e em } \\
\text { negócio jurídico; } \\
\text { reconhecimento da } \\
\text { posse pelo uso de fato } \\
\text { da terra; } \\
\text { Impossibilidade de } \\
\text { comprovar posse por } \\
\text { meio de documentos } \\
\text { de propriedade e em } \\
\text { negócio jurídico. }\end{array}$ \\
\hline $\begin{array}{l}\text { Agronegócio e } \\
\text { desenvolvimento }\end{array}$ & $\begin{array}{l}\text { Importância às } \\
\text { atividades econômicas } \\
\text { do agronegócio. }\end{array}$ & $\begin{array}{l}\text { Contextualização dos } \\
\text { conflitos envolvendo o } \\
\text { agronegócio. }\end{array}$ & \\
\hline $\begin{array}{l}\text { Forma de vida } \\
\text { das comunidades }\end{array}$ & $\begin{array}{l}\text { Equiparação a casos de } \\
\text { invasões coletivas; } \\
\text { Criminalização de } \\
\text { moradores; } \\
\text { Comprovação do } \\
\text { esbulho por meio de } \\
\text { ocorrência policial. }\end{array}$ & $\begin{array}{l}\text { Cumprimento da função } \\
\text { social da propriedade; } \\
\text { Proteção da forma de } \\
\text { vida da comunidade; } \\
\text { Trabalho na terra com } \\
\text { base na economia } \\
\text { familiar; } \\
\text { Cumprimento da função } \\
\text { social da propriedade; } \\
\text { Descumprimento da } \\
\text { Convenção n. } 169 \text { da } \\
\text { OIT. }\end{array}$ & $\begin{array}{l}\text { Proteção da forma de } \\
\text { vida da comunidade. }\end{array}$ \\
\hline
\end{tabular}

A Tabela 2 possibilita identificar as concepções a respeito de posse, agronegócio e desenvolvimento, e modelo de vida das comunidades, associadas às paráfrases elaboradas com relação ao material analisado. Assim, quanto à advocacia alinhada aos interesses da empresa, observa-se uma concepção de direito individual, formal e abstrato, além da influência do discurso do desenvolvimento e da colonialidade do poder em relação à primazia dada ao agronegócio e à criminalização dos modelos de vida das comunidades.

No que diz respeito à advocacia em defesa dos direitos das comunidades, em especial associada à advocacia popular, observa-se uma compreensão de posse associada à coletividade, atentando ao uso secular da terra e à agricultura familiar. Ademais, contextualiza-se a problemática envolvendo o desenvolvimento, por um lado, e destaca-se a importância do modo de vida das comunidades, por outro. Há, assim, uma ruptura em relação ao modelo proposto pelo agronegócio e consequentemente, à colonialidade que ele carrega. 
Por fim, o judiciário atua de modo ambíguo, possibilitando a continuidade do agronegócio, do modelo de desenvolvimento e da colonialidade de poder que os envolve. Por outro, é capaz de reconhecer a importância da tutela do modo de vida das comunidades, compreendendo a posse de maneira coletiva e rechaçando sua redução a documentos formais de propriedade.

\section{CONSIDERAÇÕES FINAIS}

Ao analisar o objeto de investigação, é possível identificar diferentes práticas jurídicas. $\mathrm{Na}$ atribuição do sentido dos termos jurídicos manuseados nas ações possessórias, pode-se identificar se estes visam ou não à manutenção de privilégios e injustiças provocados pelo agronegócio e de sua estrutura agrária. Em outros termos, a disputa dada entre o desenvolvimentismo e as comunidades autóctones, quando o projeto desenvolvimentista e a colonialidade do poder, que imprimem superioridade a esse modelo em prejuízo a outras formas de vida, é transposta para o campo do discurso jurídico.

Assim, há a utilização de ações possessórias para a manutenção de atividades econômicas, quais sejam, do agronegócio, que resultam na violação de direitos territoriais e ambientais. É o que se observou nas práticas da advocacia tradicional e do judiciário. Em outros termos, há a continuidade do monocultivo por agentes empreendedores do agronegócio, utilizando-se para tal uma leitura estritamente individual, formalista e abstrata do instrumento processo. Consequentemente, desconsideram-se, assim, os modos de vida da população camponesa.

Por outro lado, é possível identificar uma prática jurídica relacionada com lutas de acesso à terra e proteção do ambiente, como a da advocacia popular e do judiciário, quando favorável à comunidade. Com a manutenção da posse pela comunidade, entende-se a continuidade das práticas comunitárias, caracterizadas pelo uso coletivo da terra e pela agricultura familiar, associadas ao ambiente. Aqui, a posse não se resume a uma perspectiva formal da relação com a terra, mas com o uso fático da terra.

Com isso, as ações possessórias relacionam-se com as modificações do território e do meio ambiente: negativamente, quando da tutela formal em uma perspectiva individual-liberal-burguesa, alinhando-se ao cenário do discurso do desenvolvimento e da consequente colonialidade do saber e do 
poder; positivamente, com a manutenção da população e de suas atividades de produção e extração, essenciais para a sua existência enquanto grupo social.

Conclui-se, em resumo, que, por um lado o instrumento possessório pode fortalecer a luta pelo acesso e manutenção à terra pelas comunidades, com a garantia de suas práticas coletivas de agricultura, contrapostas às mudanças negativas provocadas pelo agronegócio no território e suas consequências nomeio ambiente; que por outro lado podem resultar na manutenção da estrutura agrária dominante e no aprofundamento dos conflitos sociais e danos ambientais decorrentes do agronegócio.

\section{REFERÊNCIAS}

AGUIAR, R. A. R. A crise da advocacia no Brasil: diagnóstico e perspectivas. 2. ed. São Paulo: Alfa Omega, 1994.

AUGUSTO, L. G. S. et al. Parte 2 - Saúde, ambiente e sustentabilidade. In: CARNEIRO, F. F. et al. (org.). Dossiê ABRASCO: um alerta sobre os impactos dos agrotóxicos na saúde. Rio de Janeiro, São Paulo: Expressão Popular, 2015. p. 89-191.

BRASIL. Lei $n$. 5.869, de 11 de janeiro de 1973. Institui o Código de Processo Civil. Brasília, 1973. Disponível em: http://www.planalto.gov.br/ ccivil_03/leis/L5869impressao.htm. Acesso em: 24 nov. 2019.

BRASIL. Constituição da República Federativa do Brasil de 1988. Brasília, 1988. Disponível em: http://www.planalto.gov.br/ccivil_03/ constituicao/constituicao.htm. Acesso em: 24 nov. 2019.

BRASIL. Lei n. 13.105, de 16 de março de 2015. Institui o Código de Processo Civil. Brasília, 2015. Disponível em: http://www.planalto.gov.br/ ccivil_03/_ato2015-2018/2015/lei/113105.htm. Acesso em: 24 nov. 2019.

BRASIL. Ministério do Desenvolvimento Agrário. Secretaria do Desenvolvimento Territorial. Território Baixo Parnaíba. Plano Territorial de Desenvolvimento Rural Sustentável. São Luís, 2005. Disponível em: http://sit.mda.gov.br/download/ptdrs/ptdrs_territorio020.pdf. Acesso em: 24 nov. 2019.

BRUZACA, R. D. Atuação das instituições do sistema de justiça na proteção da posse e do território nas ações possessórias ajuizadas contra comunidades quilombolas no Baixo Parnaíba Maranhense. São Luís: PAJUP, 2018. 
BRUZACA, R. D.; SOUSA, A. V. (org.). Direito achado na ilha: tutela jurídica da posse no contexto de conflito fundiário coletivo urbano no município de Paço do Lumiar/MA. São Luís: PAJUP, 2018.

BRUZACA, R. D.; VIEIRA, A. D. Linguagem dos juristas frente a representações jurídico-culturais de povos e comunidades tradicionais: o caso do conflito possessório envolvendo a comunidade quilombola de São Bento, Brejo/MA. Prisma Jurídico, São Paulo, v. 16, n. 1, p. 181-204, 2017.

CONTESTAÇÃO no Processo n. 3412009 (341-98.2009.8.10.0117) da Comarca de Santa Quitéria/MA. In: MARANHÃO. Tribunal de Justiça do Estado do Maranhão. Cível. Manutenção de posse. Processo n. 3412009 (341-98.2009.8.10.0117) da Comarca de Santa Quitéria/MA. Requerente: Comercial Agrícola e Paineiras, Cláudio Roberto Martelli. Requerido: Francisco Das Chagas Sousa Amorim. São Luís, 2014.

ESCOBAR, A. La invención del Tercer Mundo. Caracas: El Perro y la Rana, 2007.

FARIAS, C. C. F.; ROSENVALD, N. Curso de Direito Civil. v. 6. 10. ed. rev. ampl. e atual. Salvador: JusPodivm, 2014.

FLICK, U. Introdução à pesquisa qualitativa. 3. ed. Porto Alegre: Artmed, 2009.

GASPAR, R. B.; ANDRADE, M. P. Gaúchos no Maranhão: agentes, posições sociais e trajetórias em novas fronteiras do agronegócio. Revista Pós Ciências Sociais, São Luís, v. 11, n. 22, p. 109-128, jul./dez. 2014.

MARANHÃO. Tribunal de Justiça do Estado do Maranhão. Cível. Manutenção de posse. Sentença no Processo n. 3412009 (34198.2009.8.10.0117) da Comarca de Santa Quitéria/MA. Requerente: Comercial Agrícola e Paineiras, Cláudio Roberto Martelli. Requerido: Francisco Das Chagas Sousa Amorim. São Luís, 2018a.

MARANHÃO. Instituto de Terras do Maranhão. Petição informando necessidade de intervenção do Instituto de Terras do Maranhão. In: MARANHÃO. Tribunal de Justiça do Estado do Maranhão. Cível. Manutenção de posse. Processo n. 3412009 (341-98.2009.8.10.0117) da Comarca de Santa Quitéria/MA. Requerente: Comercial Agrícola e Paineiras, Cláudio Roberto Martelli. Requerido: Francisco Das Chagas Sousa Amorim. São Luís, 2018b. 
MARANHÃO. Tribunal de Justiça do Estado do Maranhão. Cível. Interdito proibitório. Oficio n. 1332012 no Processo n. 3632011 (36388.2011.8.10.0117) da Comarca de Santa Quitéria/MA. Requerente: Alberto Alves de Araujo, Cidelia Alves de Araujo, Clemilton Alves de Araujo, Elieude Gonçalves de Paula, Francisco Mota de Sousa, Gilson de Sousa Viana, Jean Araujo de Sousa, João Rodrigues dos Santos, Jose Alves Viana, José Gonzaga Araújo de Sousa, José Viana de Sousa, Josecivaldo dos Santos Viana, Josiane Araújo de Sousa, Marilene de Sousa Viana, Maria José Alves de Araújo, Marly Viana dos Santos, Noemia Alves de Araújo, Osmarino dos Santos Sousa, Raimundo Viana de Sousa, Sebastião Alves Viana, Vanderley Araújo de Sousa. Requerido: Suzano Papel e Celulose LTDA. São Luís, 2012a.

MARANHÃO. Tribunal de Justiça do Estado do Maranhão. Agravo de Instrumento n. 0079872012 (0001338-39.2012.8.10.0000). Acordão $n$. 117422012. Agravante: Suzano Papel e Celulose S.A. Apelados: Alberto Alves de Araujo, Cidelia Alves de Araujo, Clemilton Alves de Araujo, Elieude Gonçalves de Paula, Francisco Mota de Sousa, Gilson de Sousa Viana, Jean Araujo de Sousa, João Rodrigues dos Santos, Jose Alves Viana, José Gonzaga Araújo de Sousa, José Viana de Sousa, Josecivaldo dos Santos Viana, Josiane Araújo de Sousa, Marilene de Sousa Viana, Maria José Alves de Araújo, Marly Viana dos Santos, Noemia Alves de Araújo, Osmarino dos Santos Sousa, Raimundo Viana de Sousa, Sebastião Alves Viana, Vanderley Araújo de Sousa. São Luís, 2012b.

MARANHÃO. Tribunal de Justiça do Estado do Maranhão. Cível. Manutenção de posse. Decisão Liminar de 4 de agosto de 2011 no Processo n. 3412009 (341-98.2009.8.10.0117) da Comarca de Santa Quitéria/MA. Requerente: Comercial Agrícola e Paineiras, Cláudio Roberto Martelli. Requerido: Francisco Das Chagas Sousa Amorim. São Luís, 2011a.

MARANHÃO. Tribunal de Justiça do Estado do Maranhão. Cível. Interdito proibitório. Decisão Liminar de 11 de outubro de 2011 no Processo $n$. 3632011 (363-88.2011.8.10.0117) da Comarca de Santa Quitéria/MA. Requerente: Alberto Alves de Araujo, Cidelia Alves de Araujo, Clemilton Alves de Araujo, Elieude Gonçalves de Paula, Francisco Mota de Sousa, Gilson de Sousa Viana, Jean Araujo de Sousa, João Rodrigues dos Santos, Jose Alves Viana, José Gonzaga Araújo de Sousa, José Viana de Sousa, Josecivaldo dos Santos Viana, Josiane Araújo de Sousa, Marilene de Sousa Viana, Maria José Alves de Araújo, Marly Viana dos Santos, Noemia 
Alves de Araújo, Osmarino dos Santos Sousa, Raimundo Viana de Sousa, Sebastião Alves Viana, Vanderley Araújo de Sousa. Requerido: Suzano Papel e Celulose LTDA. São Luís, 2011 b.

MARANHÃO. Tribunal de Justiça do Estado do Maranhão. Cível. Reintegração de Posse. Decisão de revogação de liminar de 13 de janeiro de 2010 no Processo n. 1912009 (191-20.2009.8.10.0117) da Comarca de Santa Quitéria/MA. Requerente: Suzano Papel e Celulose S.A. Requerido: Francisca e Sebastião. São Luís, 2010a.

MARANHÃO. Tribunal de Justiça do Estado do Maranhão. Cível. Reintegração de Posse. Decisão de revogação de liminar de 16 de maio de 2010 no Processo n. 1912009 (191-20.2009.8.10.0117) da Comarca de Santa Quitéria/MA. Requerente: Suzano Papel e Celulose S.A. Requerido: Francisca e Sebastião. São Luís, 2010b.

MARANHÃO. Tribunal de Justiça do Estado do Maranhão. Cível. Reintegração de Posse. Decisão liminar de 2 de junho de 2009 no Processo n. 1912009 (191-20.2009.8.10.0117) da Comarca de Santa Quitérial $M A$. Requerente: Suzano Papel e Celulose S.A. Requerido: Francisca e Sebastião. São Luís, 2009a.

MARANHÃO. Tribunal de Justiça do Estado do Maranhão. Provimento $n$. 29/2009, de 11 de agosto de 2009, Corregedoria-Geral da Justiça. Dispõe sobre recomendação aos(às) Juizes(as) de Direito do Estado do Maranhão para que ouçam o Ministério Público do Maranhão, a Ouvidoria Agrária Nacional, o INCRA e o ITERMA em ações de manutenção e reintegração de posse coletiva envolvendo imóveis rurais ocupados por trabalhadores rurais sem-terra. São Luís, 2009b. Disponível em: https://www.mpma. $\mathrm{mp}$.br/arquivos/CAOPDH/20090820_provimento_n_29_recomendacao_ ouvidoria_agraria.pdf. Acesso em: 24 de nov. 2018.

MARANHÃO. Tribunal de Justiça do Estado do Maranhão. Cível. Reintegração de Posse. Juizo de retratação de 25 de setembro de 2009 no Processo n. 1912009 (191-20.2009.8.10.0117) da Comarca de Santa Quitéria/MA. Requerente: Suzano Papel e Celulose S.A. Requerido: Francisca e Sebastião. São Luís, 2009c.

MARQUES, M. I. M. A territorialização da empresa Suzano no campo em São Paulo e no Maranhão. Revista GeoNordeste, São Cristóvão, ano XXVII, n. 2, p. 213-227, jul./dez. 2016. Disponível em: https://seer.ufs. 
br/index.php/geonordeste/article/view/6160/pdf. Acesso em: 204 de nov. 2018 .

MIAILLE, M. Introdução crítica ao Direito. 3. ed. Lisboa: Estampa, 2005.

MIGNOLO, W. Projetos globais, histórias locais: colonialidade, saberes subalternos e pensamento liminar. Belo Horizonte: UFMG, 2011.

PAINEIRAS. Petição informando degradação ambiental.In: MARANHÃO. Tribunal de Justiça do Estado do Maranhão. Cível. Manutenção de posse. Processo n. 3412009 (341-98.2009.8.10.0117) da Comarca de Santa Quitéria/MA. Requerente: Comercial Agrícola e Paineiras, Cláudio Roberto Martelli. Requerido: Francisco Das Chagas Sousa Amorim. São Luís, 2013.

PAINEIRAS. Petição inicial. In: MARANHÃO. Tribunal de Justiça do Estado do Maranhão. Cível. Manutenção de posse. Processo n. 3412009 (341-98.2009.8.10.0117) da Comarca de Santa Quitéria/MA. Requerente: Comercial Agrícola e Paineiras, Cláudio Roberto Martelli. Requerido: Francisco Das Chagas Sousa Amorim. São Luís, 2009.

QUIJANO, A. Colonialidade do poder, eurocentrismo e América Latina. In: LANDER, E. (Org.). Colonialidade do saber: eurocentrismo e ciências sociais. Perspectivas latino-americanas. Buenos Aires: CLACSO, 2005. p. 117-142.

QUIJANO, A. El fantasma Del desarrollo en América Latina. Rer. Venez. de Econ. Y Ciencias Sociales, v. 6, n. 2, p. 73-90, mayo./ago. 2000.

RIBEIRO JÚNIOR, J. A. S.; OLIVEIRA, D. M. V.; COSTA, S. B. Desenvolvimento, conflitos e impactos ambientais: a territorialização da Suzano e a resistência camponesa na mesorregião do Leste Maranhense. Geographia Opportuno Tempore, Londrina, v. 1, n. 2, p. 11-33, jul./dez. 2014.

SANTOS, B. S. Direitos humanos, democracia e desenvolvimento. In: SANTOS, B. S.; CHAUÍ, M. Direitos humanos, democracia e desenvolvimento. São Paulo: Cortez, 2013. p. 41-133.

SANTOS, B. S. Para uma revolução democrática da justiça. 3. ed. São Paulo: Cortez, 2011.

SEGATO, R. L. Identidades políticas/Alteridades históricas: una crítica a las certezas del pluralismo global. In: SEGATO, R. L. La Nación y sus 
Otros: raza, etinicidad y diversidad religiosa en tiempos de Políticas de la Identidad. Buenos Aires: Prometeo, 2007. p. 37-70.

SHIRAISHI NETO, J.A particularização do universal: povos e comunidades tradicionais face às Declarações e Convenções Internacionais. Prefácio. In: SHIRAISHI NETO, J. Direito dos povos e das comunidades tradicionais no Brasil: declarações, convenções internacionais e dispositivos jurídicos definidores de uma política nacional. Manaus: UEA, 2007. p. 25-52.

SHIVA, V. Monoculturas da mente: perspectivas da biodiversidade e da biotecnologia. São Paulo: Gaia, 2003.

SMDH - SECRETARIA MARANHENSE DE DIREITOS HUMANOS. Agravo de instrumento em face de decisão liminar de 2 de junho de 2009 no Processo n. 1912009 (191-20.2009.8.10.0117). In: MARANHÃO. Tribunal de Justiça do Estado do Maranhão. Cível. Reintegração de Posse. Processo n. 1912009 (191-20.2009.8.10.0117) da Comarca de Santa Quitéria/MA. Requerente: Suzano Papel e Celulose S.A. Requerido: Francisca e Sebastião. São Luís, 2009b.

SMDH - SECRETARIA MARANHENSE DE DIREITOS HUMANOS. Contestação no Processo n. 1912009 (191-20.2009.8.10.0117). In: MARANHÃO. Tribunal de Justiça do Estado do Maranhão. Cível. Reintegração de Posse. Processo n. 1912009 (191-20.2009.8.10.0117) da Comarca de Santa Quitéria/MA. Requerente: Suzano Papel e Celulose S.A. Requerido: Francisca e Sebastião. São Luís, 2009a.

SMDH - SECRETARIA MARANHENSE DE DIREITOS HUMANOS. Petição inicial do Processo n. 3632011 (363-88.2011.8.10.0117). In: MARANHÃO. Tribunal de Justiça do Estado do Maranhão. Cível. Interdito proibitório. Processo n. 3632011 (363-88.2011.8.10.0117) da Comarca de Santa Quitéria/MA. Requerente: Alberto Alves de Araujo, Cidelia Alves de Araujo, Clemilton Alves de Araujo, Elieude Gonçalves de Paula, Francisco Mota de Sousa, Gilson de Sousa Viana, Jean Araujo de Sousa, João Rodrigues dos Santos, Jose Alves Viana, José Gonzaga Araújo de Sousa, José Viana de Sousa, Josecivaldo dos Santos Viana, Josiane Araújo de Sousa, Marilene de Sousa Viana, Maria José Alves de Araújo, Marly Viana dos Santos, Noemia Alves de Araújo, Osmarino dos Santos Sousa, Raimundo Viana de Sousa, Sebastião Alves Viana, Vanderley Araújo de Sousa. Requerido: Suzano Papel e Celulose LTDA. São Luís, 2011. 
SMDH - SECRETARIA MARANHENSE DE DIREITOS HUMANOS. Réplica. In: MARANHÃO. Tribunal de Justiça do Estado do Maranhão. Cível. Interdito proibitório. Processo n. 3632011 (363-88.2011.8.10.0117) da Comarca de Santa Quitéria/MA. Requerente: Alberto Alves de Araujo, Cidelia Alves de Araujo, Clemilton Alves de Araujo, Elieude Gonçalves de Paula, Francisco Mota de Sousa, Gilson de Sousa Viana, Jean Araujo de Sousa, João Rodrigues dos Santos, Jose Alves Viana, José Gonzaga Araújo de Sousa, José Viana de Sousa, Josecivaldo dos Santos Viana, Josiane Araújo de Sousa, Marilene de Sousa Viana, Maria José Alves de Araújo, Marly Viana dos Santos, Noemia Alves de Araújo, Osmarino dos Santos Sousa, Raimundo Viana de Sousa, Sebastião Alves Viana, Vanderley Araújo de Sousa. Requerido: Suzano Papel e Celulose LTDA. São Luís, 2012.

SUZANO. Agravo de instrumento. In: MARANHÃO. Tribunal de Justiça do Estado do Maranhão. Cível. Interdito proibitório. Processo n. 3632011 (363-88.2011.8.10.0117) da Comarca de Santa Quitéria/MA. Requerente: Alberto Alves de Araujo, Cidelia Alves de Araujo, Clemilton Alves de Araujo, Elieude Gonçalves de Paula, Francisco Mota de Sousa, Gilson de Sousa Viana, Jean Araujo de Sousa, João Rodrigues dos Santos, Jose Alves Viana, José Gonzaga Araújo de Sousa, José Viana de Sousa, Josecivaldo dos Santos Viana, Josiane Araújo de Sousa, Marilene de Sousa Viana, Maria José Alves de Araújo, Marly Viana dos Santos, Noemia Alves de Araújo, Osmarino dos Santos Sousa, Raimundo Viana de Sousa, Sebastião Alves Viana, Vanderley Araújo de Sousa. Requerido: Suzano Papel e Celulose LTDA. São Luís, 2012b.

SUZANO. Apelação. In: MARANHÃO. Tribunal de Justiça do Estado do Maranhão. Cível. Reintegração de Posse. Processo n. 1912009 (19120.2009.8.10.0117) da Comarca de Santa Quitéria/MA. Requerente: Suzano Papel e Celulose S.A. Requerido: Francisca e Sebastião. São Luís, 2009 b.

SUZANO. Contestação. In: MARANHÃO. Tribunal de Justiça do Estado do Maranhão. Cível. Interdito proibitório. Processo n. 3632011 (36388.2011.8.10.0117) da Comarca de Santa Quitéria/MA. Requerente: Alberto Alves de Araujo, Cidelia Alves de Araujo, Clemilton Alves de Araujo, Elieude Gonçalves de Paula, Francisco Mota de Sousa, Gilson de Sousa Viana, Jean Araujo de Sousa, João Rodrigues dos Santos, Jose Alves Viana, José Gonzaga Araújo de Sousa, José Viana de Sousa, Josecivaldo 
dos Santos Viana, Josiane Araújo de Sousa, Marilene de Sousa Viana, Maria José Alves de Araújo, Marly Viana dos Santos, Noemia Alves de Araújo, Osmarino dos Santos Sousa, Raimundo Viana de Sousa, Sebastião Alves Viana, Vanderley Araújo de Sousa. Requerido: Suzano Papel e Celulose LTDA. São Luís, 2012a.

SUZANO. Perfil. 2018. Disponível em: http://www.suzano.com.br/ institucional/perfil/. Acesso em: 24 nov. 2019.

SUZANO. Petição inicial. In: MARANHÃO. Tribunal de Justiça do Estado do Maranhão. Cível. Reintegração de Posse. Processo n. 1912009 (191-20.2009.8.10.0117) da Comarca de Santa Quitéria/MA. Requerente: Suzano Papel e Celulose S.A. Requerido: Francisca e Sebastião. São Luís, 2009a.

SUZANO. Relatório de sustentabilidade de 2016. 2016. Disponível em: http://ri.suzano.com.br/a-companhia/sustentabilidade. Acesso em: 24 nov. 2018.

WOLKMER, A. C. Pluralismo jurídico: fundamentos de uma nova cultura no Direito. 3. ed. rev. e atual. São Paulo: Alfa Omega, 2001.

Artigo recebido em: 11/03/2019.

Artigo aceito em: 04/09/2019.

\section{Como citar este artigo (ABNT):}

BRUZACA, R. D.; VIEIRA, A. D. Impactos territoriais e ambientais nos conflitos possessórios com as empresas Suzano e Paineiras no Baixo Parnaíba Maranhense. Veredas do Direito, Belo Horizonte, v. 16, n. 36, p. 247-278, set/dez. 2019. Disponível em: http://www.domhelder.edu.br/ revista/index.php/veredas/article/view/1501. Acesso em: dia mês. ano. 